\title{
Northern Ireland in Transition: The Role of Justice
}

\author{
Christian Mailhes \\ Université des Sciences Sociales, Toulouse 1
}

\begin{abstract}
Copyright (c) 2005 by Christian Mailhes. This text may be archived and redistributed in electronic form, provided that the author and journal are properly cited and no fee is charged for access. Archiving, redistribution, or republication of this text on other terms, in any medium, requires the notification of the journal and consent of the author.
\end{abstract}

\begin{abstract}
All post-conflict societies switching to constitutional liberal democracies have to deal with their past through transitional justice mechanisms that offer to hear the victims, try the perpetrators of all types of abuses, introduce peace and reconciliation schemes. It is time for state and non-state organs to account for past crimes. Several countries have successfully tested such mechanisms. Northern Ireland is the ideal ground for transitional justice to operate but it dispels foreign tailor-made models. However, a number of major reforms and projects have addressed sensitive issues in the wake of the Good Friday Agreement. Two key institutions, the police and the criminal justice system, whose responsibility in the conflict was undeniable, have been reformed. Law and lawyers are concerned with these changes and the introduction of a Human Rights culture in Northern Ireland. A clear break with the past must be achieved for transitional justice mechanisms to work successfully.
\end{abstract}

Key Words : Criminal Justice system, Emergency Legislation, Human Rights, Northern Ireland, Peace Process, Good Friday Agreement, PSNI, Restorative justice, Transitional Justice, Truth and Reconciliation Commission.

After a period of brutal conflict, any state must move on from the violence and recover from its wounds and trauma. To do so, postconflict countries will often look back to identify the root causes of the violence, provide justice for victims and generate ways to prevent future human rights abuses. This is often a difficult transition that involves a wide range of actors and may take years to accomplish.

Northern Ireland has undergone decades of protracted armed internal conflict, unresolved by military and security policies, draconian permanent emergency legislation or attempts at political normalisation. However, political normalisation became possible in 1998 with the Good Friday Agreement which opened an era of transition. The document therefore offers a framework for transition so that such a deeply divided society may proceed towards re-establishing itself. Since then, in spite of its current institutional deadlock, Northern Ireland has been undergoing a dynamic process to deal with its past. A number of reforms in the most sensitive areas of policing and criminal justice have been launched by the Agreement.

The Agreement was an attempt at bringing together apparently irreconcilable claims from Northern Ireland's political parties in order to envisage a new start and a common future for all citizens. However, after decades of violent entrenched conflict and thousands of victims, a number of conflict-related issues with important legal dimensions remain to be addressed. 
In all states which have switched from authoritarian regimes or conflict-riven societies to constitutional liberal democracies, some form of transitional instruments has been put in place. It has necessarily required the intervention of legal mechanisms offering common neutral ground to respond to past conflicts. Since the 1980s, a number of states - following civil war, military dictatorships or communist regimes - have had to adopt a number of legal instruments to address the past which were part of a global scheme known as transitional justice. The aim is to hear victims' and survivors' demands for justice and reparations, bring redress for past wrongs, restore peace and confidence and ideally reconcile former enemies. Thus transitional justice is the process by which nations which have been submitted to a period of brutal conflict address past abuses with a view to reforming their society through institutional change. In most conflicts, gross abuses of human rights are committed, mostly against the most vulnerable, and it is essential that abuses should be confronted, otherwise the ideology behind past abuses may remain unchecked. That is why transitional states find it important to incorporate a number of different transitional justice mechanisms. The complex nature of human rights crises prove that dealing with only one factor of the past abuses will not bring about a peaceful transition or justice to the victims. Accountability for the past should be an important step towards peace in the future, especially between differing parties or communities within a state.

This paper will briefly explain how transitional justice has developed since the 1980s, how Northern Ireland offers a ground for such mechanisms to operate a transition towards normalisation and what changes are needed or have already been brought about. The legal world is of course at the core of transition in Northern Ireland as justice for all needs to be implemented in the context of a real change.

\section{1 - What is transitional justice?}

Transitional justice is a wide heading for all political and legal reforms led in the postconflict transition. It has focused attention and produced a huge amount of legal literature over the last twenty years. Therefore it is still new ground with teething problems that offer uncommon and transitory remedies to postconflict situations. However, it is different from ordinary justice which may be called upon to operate but which, in so many cases, may have been so tainted by years of violence that it also has to undergo a process of change. Transitional justice does not offer one global response to one specific situation but rather a number of solutions that may complement each other.

The concept emerged in the 1980s in Latin America when structured transition from military to civilian rule was established. Then a substantial production of academic literature on the "irredeemable state facing transformation" (Campbell et alia 2003: 334) which sought to analyze the political responses to radical change. From Latin American transitions, concern switched to Central and Eastern Europe in the wake of the fall of the Berlin Wall and to the transition framed by the peace processes in South Africa. ${ }^{1}$ A number of questions were asked: how do we heal the past? how can the future be envisaged along new equitable rules if the past keeps haunting people's consciences? At the heart of all academic analysis of the new trend, there was a widespread awareness that the law and legal systems would be playing a most fundamental role to support and favour transition from a violent conflict situation or an authoritarian regime towards peace and democracy. The mechanisms put in place in periods of transitional justice can truly be considered as relevant remedies when democratically elected leaders replace dictatorial leaders and their draconian policies alleged to have been responsible for gross violations of human rights

In most cases of violent conflict, law was instrumental in creating and fuelling the conflict since law was used and abused by those in power. In other words, law was part and parcel of the conflict and certainly not a neutral or alien instrument to it. For years, ordinary law may have departed from its original function, being used 'ultra vires" those whose power rested on its enforcement. Therefore transition demands that new legal structures be set up, indeed new legislation has to play a dynamic part in the common demand for justice and change, emphasizing a clear and definitive break with the past. Law must be the foundation on which social renewal is being 
established along fair and equitable principles in order to restore the confidence of all citizens. However, new legislation has to face a paradoxical situation: on the one hand, it has to maintain law and order while on the other, it has to play a dynamic role towards radical change. In a transitional period, the scope of political change is such that the paradoxical quality of law is extraordinarily amplified. ${ }^{3}$

Previous law and legal systems may therefore be a difficult legacy and a great demand for change can only be satisfied if neutral and international legal instruments are introduced. This is why international law offers a spate of principles alien to the parties involved in the conflict.

In societies in transition, international legal principles are necessary to design a legal framework not only to protect human rights but also to redress the past. It helps address what degree of democratic values will be used by transitional governments to acknowledge the grave violations committed by previous regimes. This will obviously raise such complex issues as truth telling to assess the past and how it will help reconciliation, how efficient trials can be in order to establish accountability and restore the confidence of the community across the ideological divide.

Moreover, the central issue for a state in transition is the institutional legacy, an area where law has played and will play a major role. Though the role of security forces has been railed in the conflict and should therefore be among the first state organs to be thoroughly reformed, the criminal legal system and the courts that operated it should also undergo drastic changes so as to send clear signals of a new beginning. The importance given to the law and relevant institutions in a situation of change must emphasize a sheer break between past and future. While peace negotiations are being conducted, it is difficult to frame new institutions from scratch without referring to pre-existing ones exercising the same functions. In most cases, new institutional organs are set up on the foundations of previous institutions. Therefore, it is preferable that transition should be a phase when new institutions are transformed, merging the old and the new, rather than reformed, as in South Africa. ${ }^{4}$

Therefore which international instruments deserve attention when seeking redress for past wrongs and envisaging new legislation? There are two kinds of sources on which to draw extensively: international humanitarian law and Human rights law. After the Second World War, the 1949 Geneva conventions launched the development of international humanitarian law, contemplating reparations for violations of civilians' rights and property in all sorts of armed conflicts. ${ }^{5}$ International humanitarian law applies in cases of war and is often referred to by transitional justice experts. Under international law, there is a clear obligation to repair whenever states have violated human rights. ${ }^{6}$ The other source of legal reference is Human Rights law established by international organisations in well-known instruments that have played a major role in the Good Friday Agreement negotiations and which were repeatedly referred to during the conflict.

Unlike Human Rights law, international humanitarian law directly addresses an armed situation whose responsibility concerns all participants therefore creating a challenge for each concerned since not only the state but all non-state actors as well are concerned. Since international humanitarian law addresses a war situation, it automatically admits the political dimension of the conflict which makes the state not the victim of the conflict but also an active participant. That's the reason why states facing internal conflicts try to avoid applying international humanitarian law until peace negotiations have started unless human rights violations become intolerable. In Northern Ireland, reference to international humanitarian law has been avoided even in the post conflict period.

Reparation is part of transitional justice. It is a very broad term that may address legal, psychological, moral and financial evils suffered by the victims. In transition periods, reparatory justice is expected to bring redress to victims as it implies rectification of past wrongs. However, the question of reparatory justice is a complex issue raising debates between compensating victims of past state abuses and the state immediate or future political interests. The obligations under international humanitarian law "regarding reparations to abused victims of other states led to the national obligations to compensate citizens for violations" (Teitel 123). Then transitional reparatory obligations have been decided in purely internal conflicts. In accepting to pay reparations, the successor 
regime takes responsibility for the past regime's abuses. Transitional reparations aim at restoring victims but they also seek to restore a balance that was disrupted by the previous regime. This has been the case in several Latin American countries (Chile, Honduras, Argentina). Moral reparations sought to restore the victims' dignity, repair the humiliation inflicted on them and rehabilitate their reputation and equal status in the public opinion. The function of law is to advance transition in periods of radical change: law does so when it recognizes the state's past wrongdoings, restores victims and reestablishes the legal system. However, the time factor has to be taken into account since "with the passage of time, reparatory projects move farther from the traditional model of corrective justice. After time, wrongdoers don't pay; innocents do" (Teifel, 141).

Indeed, transitional justice offers a broad framework to the many types of political and legal changes occurring in the transition between conflict and reform. Problems may arise from the conflict-related legal institutions as well as from legal and ethical dilemmas pertaining to the post-conflict era. A number of mechanisms have been used throughout the world to bring about reform. Some of the most common transitional justice mechanisms have been to:

- Try perpetrators in a court or war crimes tribunal for the crimes committed during the crisis.

- Offer reparations to all those who suffered abuse.

- $\quad$ Set up truth and reconciliation commissions.

- Remove those who violated human rights from office.

- Promote civic education on transitional justice and human rights.

- Inform the public on transitional justice mechanisms and facilitate consultation and brainstorming workshops.

- Reform institutions whose agents abused human rights.

- Identify and promote structural changes within companies that collaborated or benefited from collaboration with past dictatorships.

- Have officials acknowledge past abuses and offer an apology.

- Declare blanket amnesties.

- Control of future judicial and governmental institutions.
- $\quad$ Provide psychological support to survivors of human rights abuses and their perpetrators.

- $\quad$ Provide measures to implement disarmament and reintegration for former fighters.

- Conduct cleansing ceremonies or organise events of artistic expression to promote reconciliation and reintegration of perpetrators and victims in society.

Certain mechanisms and combinations of tactics are more effective in some countries than in others, depending on whether their history involved civil or international war, or a brutal leadership that tortured the population. Each country's experience with human rights abuses is different and its cultural context also causes variation in the transitional tactics employed.

It will therefore be informative to discover what mechanisms have been put in place in Northern Ireland.

\section{2 - Northern Ireland in transition}

Northern Ireland offers ideal ground for transitional justice. The Good Friday Agreement is a transition document allowing to go through the uneasy threshold between past and future. It offers a legal basis for change at different levels (political, institutional, social legal) in a normally peaceful and stable transition. Change was also highlighted by the actual participation of former alien elements now drawn to the centre of decision-making organs. Though transitional justice strategies have applied elsewhere (mostly in Latin America, Central Europe and of course in South Africa), it seems Northern Ireland remains a case apart and that foreign transition models cannot be adopted so easily. Indeed Northern Ireland stands as a unique case: first of all, the conflict was fought under the umbrella of the British government offering a democratic model of government, and on the other hand, the various political protagonists to the Agreement have never fully committed themselves to implement the provisions they supported. The transition period in Northern Ireland is tragically haunted by history: the break with the past has not yet been completed, which explains why it is so difficult to move forward. The transition is in a deadlock, the institutions are suspended, all the reforms that have been launched have been severely criticised, the 
work of the Human Rights commission and the drafting of a Bill of Rights bitterly decried by some quarters. This is a paradoxical situation: why is it that unlike most countries going through a phase of transition, Northern Ireland seems to find that period more problematic despite a liberal democratic tradition. In fact, transition is not easy for two major reasons: probably because of the nature of a very violent conflict whose protagonists have tenaciously bargained the terms of the Agreement until the very end while being encouraged to proceed by the British and Irish governments. Secondly, the state's failure to acknowledge past mistakes and abuses committed by its institutions and agents. The role of the British state is ambiguous indeed since it was both a participant in the conflict though it managed at the same time to reach an agreement about an internal conflict that took place on its own territory. As the state could not clearly admit it, it placed itself above it. For the state, political violence simply amounted to criminal activity which required a tough immediate security response. That may be one of the reasons why international humanitarian law was eschewed from public discourse during the conflict in spite of occasional references to a war situation both by the state and paramilitary factions. The latter persistently referred to the war rhetoric without mentioning humanitarian law, which may have been the consequence of their own ignorance or simply because it would have limited their military actions.

As long as the peace process had not made much progress, the British government could not adopt humanitarian law completely for it had not ratified two 1977 Protocols to the Geneva conventions concerning unconventional armed conflict. ${ }^{7}$ However, other humanitarian legal instruments were available during the Troubles and the NGOs which appeared in Northern Ireland throughout the 1990s referred to different humanitarian documents which were not necessarily influenced by humanitarian law. For the state, the security problems were different from political ones: political violence was therefore criminalised as the state pretended such behaviour could in no way have political motivation, thus denying the existence of an armed conflict and any logical reference to the law of war.
However, the British government indirectly did admit a number of institutional failings which the proposed reforms in the Agreement tended to redress such as the police, the criminal justice system and a better protection of individual rights. As in all societies in transition, the Agreement tended to make proposals on how to deal with the past and the institutional legacy. Unlike other countries in a similar situation, Northern Ireland was not the result of a dictatorial regime but the problem actually lies with determining the responsibility of all participants in the conflict (state and non-state agents).

In most post-conflict societies, emphasis is laid on moral and criminal accountability as part of the conciliation and sometimes of the Agreement. In Northern Ireland, the Agreement only makes limited reference to the past through these words: "The tragedies of the past have left a deep and profoundly regrettable legacy of suffering.", which created so much anger and frustration among the victims of the conflict. This may be explained by the parties refusing to get involved further in assessing the past, a process by which they would have more to lose than gain. Contrary to South Africa, where transition was considered as a case in point by Northern Ireland reform commissions, the Agreement does not recommend a specific instrument to assess the past such as the Truth and Reconciliation Commission in South Africa, simply because there was no consensus among the signatories. In South Africa, an amnesty became part of the transition agreement in exchange for truth and reconciliation. The 1993 Constitution entitled 'National Unity and Reconciliation' provided "In order to advance such reconciliation and reconstruction, amnesty shall be granted in respect of acts, omissions and offences associated with political objectives and committed in the course of the conflicts of the past". ${ }^{8}$ In addition, the Constitutional Court held that amnesty should include the clarification of past political crimes and their reparation, so the two were irremediably connected. ${ }^{9}$ This form of transitional redress became an alternative to punishment since criminal sanction would not be suitable for transitional practice. However, if the past was ignored despite its stark human rights abuses, Paragraph 2 of the Agreement makes provision for the future with the entrenchment in UK legislation of the European Convention on 
Human Rights. The Human Rights Act 1998 can only address the future and certainly not deal with the state agents' past abuses of human rights. This obviously indicates how reluctant the government, its agencies and nonstate organisations are to assess their roles throughout the Troubles.

In spite of such reluctance a number of measures have been carried out in Northern Ireland, going from thorough reforms of the police and criminal justice systems to other transitional justice mechanisms aimed at remedying a number of issues. For example, outside the frame of the Agreement and under repeated pressure from families, NGOs, and human rights organisations, the British government accepted to investigate the past by setting up the Saville inquiry ${ }^{10}$ into the Bloody Sunday shootings of 30 January 1972 in Londonderry and by agreeing with the Irish government to appoint Canadian judge Peter Cory to reexamine eight murder cases involving alleged police collusion on both sides of the border. ${ }^{11}$ Judge Cory was empowered to recommend a public Inquiry whenever necessary. This was a poor acknowledgement of what the past had been which leaves aside a number of sensitive issues that should have been openly addressed, among which draconian emergency legislation but into place as early as 1922 and never repealed since then. Broader transitional justice debates are now underway. For the time being, various transitional justice initiatives have been, with or more less success, launched or completed, such as:

a) decommissioning of weapons by paramilitary organisations, mostly the IRA.

b) the release of political prisoners as announced by the Belfast Agreement,

c) court cases focusing on state violence such as those taken to the European Court of Human Rights, ${ }^{12}$

d) the creation of a Human Rights Commission whose work has consisted in assessing the needs, developing a Human Rights culture, raising awareness as to individual rights. It has also launched a vast consultation campaign across Northern Ireland to establish the needs and draft a Bill of Rights for Northern Ireland, ${ }^{13}$ e) the completion after three years of the hearings of the Bloody Sunday Inquiry,

f) the release of the Steven's Inquiry into police collusion concerning the murder of Pat Finucane,

g) the official report from appointed Canadian judge Peter Cory as to whether further inquiries into additional cases are needed, especially the sensitive cases of two murdered solicitors, Pat Finucane and Rosemary Nelson, for allegations of collusion between security forces and loyalist paramilitaries,

h) a wide consultation process by the 'Healing Through Remembering Project' regarding methods and strategies for dealing with the past, ${ }^{14}$

i) the Chief Constable's call for a truth commission, claiming that he did not have the resources to investigate all the unsolved cases,

On the whole, the reluctance to address the past is obvious in the way the victims of the conflict have been dealt with. Measures to investigate such a vast sensitive area had been taken before the Good Friday Agreement was signed and lip service paid to them in the Agreement without formal provision to deal with them: "..it is essential to acknowledge and address the suffering of the victims of violence as a necessary element of reconciliation". Perhaps the launch of the Bloomfield Report roughly at the same time was a gesture that compensated for this failure. The Victims Commissioner, Sir Kenneth Bloomfield established the needs of the victims, which was the first time a public official had done so in three decades. ${ }^{15}$ Yet his Report was criticised for failing to recommend a Truth and Reconciliation Commission for Northern Ireland and not emphasising clearly enough the experiences of victims of state violence during the Troubles. ${ }^{16} \mathrm{~A}$ limited number of victims or survivors or their representatives demand that their plight be acknowledged, their voices heard and reparation awarded. In Northern Ireland as in all countries riven by decades of conflict, there is a strong need to articulate personal traumatic experiences through a legally structured instrument, without which peace and reconciliation will not be complete. Those whose lives have been severely affected 
by state agents do feel particularly abandoned and have therefore turned to the European Court of Human Rights to vindicate their rights and seek redress. In a series of cases referred to the Court since April 1998, the European Court found in all first four cases in which twelve people were killed that the procedures for investigating the use of lethal force by RUC officers failed to meet the requirements of the European Convention for Human Rights. ${ }^{17}$ It is worth underlining that once again the response to respond to a painful demand did not come from the local courts but from alien organs. Among the cases submitted by the families of the victims to the Police Ombudsman of Northern Ireland, Mrs Nuala O'Loan, four were examined in which it was found that the RUC failed to conduct a proper and thorough investigation. ${ }^{18}$ Such decisions show that a number of victims expect the state to create relevant structures that will answer their questions and help unearth the truth.

However, it seems difficult to carry out new investigations into hundreds of unsolved cases owing to a lack of human and financial resources. This is what the Chief Constable, Hugh Orde, made quite clear when he supported the creation of a Truth and Reconciliation Commission on the South African model since his: "reformed force could not cope with the growing demand to reopen some of the most emotive and politically sensitive cases". ${ }^{19} \mathrm{He}$ stated there was little hope that many of the 1800 cases involving loss of life would ever be closed. This proposal had previously been suggested by the Chairman of the Policing Board, Professor Desmond Rea, as part of a move "to reconcile the losses of the past and embrace the future". ${ }^{20} \mathrm{He}$ went on :"There are people on both sides who have lost lives. There are people who have been injured and there is a deep sense of hurt. Therefore a commission is the proper way to take account of that hurt but also to seek to find a way forward than the road that we appear to be embarking". ${ }^{21}$ Professor Rea was alluding to the high cost of the Saville inquiry into the Bloody Sunday shootings and to the fact that the pressure was building up for further judicial inquiries into state collusion with loyalist paramilitaries. ${ }^{22}$ Reaction to Rea's proposal was very negative. Unionist hostility focused on the issue of amnesty but more or less, and for different reasons, all political parties refused the idea of a Truth and Reconciliation Commission. The time was premature for, unlike South Africa, the dispute was not settled yet. ${ }^{23}$ Some may fear to have to confess to past crimes and unacceptable practices under Human Rights standards. On 28 May 2004, the secretary of State for Northern Ireland, Paul Murphy, announced that he would be visiting South Africa on a fact-finding mission to study how the country had dealt with the past. Advocacy of the South African model for dealing with the past in Northern Ireland can be traced back to the years when the Truth and Reconciliation Commission began its work. After his factfinding mission to Africa, Paul Murphy underlined three prerequisites for dealing wit the past : "First, the conflict must truly be over. Then whatever methods were finally used to deal with the past "must come from the whole community and enjoy a consensus of support" - finally, there is a need for a shared vision of the future. ${ }^{24}$ In South Africa there was a consensus that apartheid had been wrong and that the quest for majority rule was justified in terms of democratic principles. Brian Feeney, one of the co-authors of "Lost Lives" 25 commented upon the announcement of Murphy's trip to Africa: "There have been about forty truth and reconciliation processes around the world in places like South Africa and Peru. The only time they have worked is when the conflict has definitely come to an end. That is not the case here". ${ }^{26}$

There is a fear indeed that such a commission might block inquiries into controversial killings. In April 2004, the British government accepted Judge Cory's recommendations that they should be inquiries into three of the four cases investigated in Northern Ireland. After postponing the decision of an inquiry into the Finucance case, the government is now placing roadblocks on the way to a full public inquiry into the case. Suspicion that the government might try to cover up security-force collusion with Loyalist paramilitaries in this case might be one major reason why the nationalist community has not enthusiastically supported the creation of a Truth and Reconciliation Commission. The reason why the government might be favourable to the principle of setting up a Commission would be to address the various issues creating frustration and discontent under the umbrella of a broad healing mechanism that would override all the objections raised 
against such an instrument. The government has repeatedly mentioned that a piecemeal treatment might be lengthy and inefficient and envisages a global solution as a breakthrough that would complement the expectations of the Good Friday Agreement. The reasons why the British government is now looking at South Africa as a possible model for Northern Ireland is that the country has undergone an unexpected transition to democracy which all the supporters of a political solution might see as a possible model to draw from. Chief Constable Hugh Orde raised the idea of an amnesty for troubles-related crimes and suggested a mechanism to achieve closure over deaths during the Troubles, which the unionist community dismissed with contempt. ${ }^{27}$ However, while some victims groups and political parties are unfavourable to a local Truth and Reconciliation Commission, a growing pressure for some such mechanism has been building up in Northern Ireland especially among local NGOs supporting the victims. Locally organised victims groups have started supporting the victims by helping them 'tell their stories', something a Truth and Reconciliation Commission would do. The government has actually been overtaken on this point. Creating a formal mechanism would mean that the government would officially commit itself to looking at the past. Or is it mere lip-service without much future involvement to address past failings? Turning to South Africa is a way of legitimising the government's response to deal with the past. But there are substantial differences between the two systems. Those who today are reluctant to introduce such a mechanism will not be ready to come forward and admit participation in crimes, whether they be former paramilitaries or security members. Moreover, prosecutions for such crimes remain unlikely, which means that without a mechanism for telling the truth and heal the past, frustration and suffering will linger on for thousands of people. No creation of a Special Court has either been suggested where conflict-related abuses would be tried.

Another area where the Agreement directly addressed the past concerns the early release of prisoners convicted in Diplock courts. ${ }^{28}$ This decision could amount to an amnesty which is a classic post-conflict scheme which created anger among the survivors or the victims' close relatives. In addition, frustration is still high as far as the juryless trial mechanism is concerned. While the security forces have been responsible for hundreds of deaths, sometimes of innocent victims, during the Troubles (and some in highly dubious circumstances), especially in the 1980s when a 'shoot-to-kill policy' was allegedly implemented, very few of them have been prosecuted and a handful only have been convicted and sentenced for such human rights abuses. Cases of collusion with loyalist paramilitary organisations have also been discovered. This sharply contrasts with the thousands of suspects prosecuted in the juryless (and ordinary) criminal courts, not to mention several 'supergrass' trials staged by the police in the 1980s which sent scores of innocent people to prison and brought disrepute on the administration of justice. These failings suggest that a substantial number of deaths by the police and the army has been unsolved by the courts. The legal system did not duly perform its function either. Consequently, it was highly urgent to reform the police force whose abuse of powers and lethal force and interrogation methods had been denounced during the Troubles both by Amnesty International and the European Court of Human Rights. ${ }^{29}$ The police reform was carried out by an independent commission, the Patten Commission ${ }^{30}$ whose report launched new legislation to institute the Police Service of Northern Ireland (PSNI). ${ }^{31}$ Following the Report, the reform was based on two major principles: accountability to the law and the community highly symbolized by the creation of the District Policing Partnerships and independence from the state and politicians by "serving the people by upholding the law that protects the rights and liberties of every individual citizen". ${ }^{32}$ As he acknowledged the failings of the past due to unlimited powers granted to the police, the Patten report quoted Lord Scarman reporting in 1981 on the Brixton disorders : "the police officer must act within the law; abuse of power by a police officer, if it allowed to occur with impunity, is a staging post to the police state". ${ }^{33}$ The police reform has been implemented and created tensions across the community divide owing to the reduction of staff and the new 50:50 recruitment policy. Yet, the number of catholics in the police service now stands at $16,3 \%{ }^{34}$ This was a substantial reform which should according to Chris Patten offer Northern Ireland "the most rigorous system of 
independent civilian oversight in the world". ${ }^{35}$ In addition, the office of the Police Ombudsman was created to deal with complaints against police forces. It has also shown independence in the Report in the Omagh bombing.

Though more ambitious or radical measures could have been taken to address the past, this will only be possible when consensus has been reached, that is when political conflict will definitely come to an end.

\section{3 - Lawyers and the courts}

As has been said, several mechanisms are being operated towards assessing the past. The criminal justice system also needs cleansing in the post conflict era. In Northern Ireland, the criminal justice system which had been at the centre of controversy and discontent throughout the Troubles is in the process of being reformed. Some considered it as a tool of coercion in the hands of the state while courts had no choice but apply statutory legislation. The latter, both at an instrumental and ideological level, had also been a recurrent area of controversy. Ever since the inception of Northern Ireland, law has mostly had a repressive role to prohibit political violence and bring sanctions on criminal offenders. The Civil Authorities (Special Powers) Act 1922, derived from previous martial law enforced over the whole of Ireland since 1914, sought to deter any kind of criminal activity and gave unlimited powers to an armed police force with extraordinary powers of arrest, search and detention. Even tough such powers "were not formally directed against Roman catholics and Republicans, it was common knowledge that it was against them and them alone that it was directed and used" (K.Boyle, T.Hadden, P.Hillyard, 7). Many commentators believe that such measures have fuelled a sense of discrimination and frustration which eventually led to spiralling violence. The main feature since the 1970 s has been to criminalise all paramilitary activity to avoid considering it as political and obtain changes in the ordinary criminal law in order to prosecute and convict those suspected of political violence. Thus the major emergency statutes, the Northern Ireland (Emergency Provisions) Acts 1973, reviewed in 1878-87 and the Prevention of Terrorism Act passed in the wake of the Birmingham bombings in November 1874, reviewed in 1989, created a number of 'new' criminal offences, allowing the police to arrest people on more broadly defined grounds and detain them for longer periods than previously allowed under the ordinary law, allow confessions to be accepted more easily, suspend trial by jury for scheduled offences and give the executive power to exclude people from one part of the United Kingdom without prior hearing. The army was also increasingly used to support the police. Many observers have contended that there was no reason for making emergency legislation permanent from 1932 onwards. However, this strategy remained legal. It enforced general criminal laws to prohibit activities such as murder, causing explosions and armed robbery.

The three decades prior to the GFA witnessed recurrent controversy over security force abuses. Situations abound in which the police or the army had exceeded or used their powers in apparently biased or partial fashion. They include questionable interrogation practices in the 1970s which led to investigations by Amnesty International as has already been mentioned, the use of lethal force by the security forces in which over 350 people were killed, ${ }^{36}$ subsequent concerns about an alleged 'shoot-to-kill' policy, concerns about supergrass trials, about abusing arrest powers to gather information, reports of collusion between elements of the security forces and loyalist paramilitaries, targeting and harassing of those living in nationalist areas. The recurrence of these claims and the fact that many still remain unsolved suggests that the rule of law did not prevail in Northern Ireland. Though the responsibility of both loyalist and republican paramilitaries for civilian deaths and injuries was clearly greater that that of the police or the army, ${ }^{37}$ it must remain a matter of concern for those who consider the rule of law as a central value in a democratic society. The words of Manchester policeman John Stalker, appointed to investigate a series of deaths resulting from security force action in Armagh in 1982 revealed that actions that exceeded available powers will not be frowned upon provided they produced results and did not injure too many innocent people: "I never did find evidence of a shoot-to-kill policy as such. There was no written instruction, nothing pinned up on the notice board. But there was a clear understanding on the part of the men 
whose job it was to pull the trigger that that was what was expected of them". ${ }^{38}$ The mechanisms to redress security force abuses in order to reassert the values of the rule of law and minimal use of force by the state were lacking. Courts brought little satisfactory remedy given that the legal standard for much disputed state action was the vague notion of "reasonableness", meaning that the intervention of a police constable or soldier to prevent a crime or arrest someone on suspicion must be reasonable.

As a rule, most Northern Ireland's lawyers have through accident or choice eschewed work related to the conflict. Both the Law Society and the Bar Council have avoided making comments on changes in the law or sending submissions to some inquiries looking at anti-terrorist law, which according to many British and international human rights observers "brought the law into disrepute by undermining the extent to which it complies with rule of law principles and international human rights standards". ${ }^{39}$ Concerning the murders of two well-known solicitors, Pat Finucane and Rosemary Nelson, the Law Society of Northern Ireland eventually passed a motion, urged by growing criticism, to press for a fuller investigation into the deaths of their colleagues. Northern Ireland's lawyers distinguished themselves for their 'tepid' response to the Finucane murder according to the 1993 Report of the Lawyers Committee on Human Rights. ${ }^{40}$ Research has shown that a relatively small number of lawyers have been working on cases related to the conflict. ${ }^{41}$ According to a barrister, a core of only twelve counsel were regularly involved in such cases. ${ }^{42}$ It has been alleged that the reason why lawyers are indifferent to sensitive cases because they wish to protect their independence by not taking sides but there may also be an element of fear for their safety and their families'. So they maintain a neutral position aloof from the highly volatile circumstances of Northern Ireland which have for so long affected and undermined the legal institution.

All the same, the judiciary has been ostracised for its partial administration of justice in a sectarian society. Under section 5 of the Government of Ireland Act 1920, the courts had the power to invalidate local legislation that might be discriminatory to one section of the community on religious grounds.
The Northern Ireland courts failed to challenge the inequalities imposed on the minority. However, since the early $70 \mathrm{~s}$, successive governments have tried to use law not just to prevent and punish political violence but also to produce political and social change which might bring about greater social consensus. The judiciary in NI have had to make do with emergency legislation and those who were brought to court under this legislation. Judges had to deal in turn with the treatment of internees, the circumstances in which confessions had been obtained before trials, supergrass trials, the curtailment of the right of silence and access to defence lawyers; as well as the legality of the use force, including lethal force, by the security forces. Judges have responded to these issues by showing a clear abhorrence of terrorism and a belief in the right of society to prevent and punish it. They have themselves, as the guardians of the law, been the targets of paramilitary attacks in which several of them died. Throughout the years of conflict, they have tried to maintain judicial independence, especially in the supergrass episode when it was admitted by the Northern Ireland Court of Appeal that the credibility problems of the so-called 'witnesses' had been underestimated or that corroboration requirements had been misapplied. Their decisions show clearly that they did not always reach similar conclusions.

Northern Ireland judges have been criticised for their lack of exacting scrutiny of cases where the police and army had used lethal force. In all cases, allegations of the use of 'reasonable' force are more than doubtful and only a handful of security force members were convicted of murder for killings committed while on duty. Acquittal rates ran at over $80 \%$, which has discouraged the bringing of prosecutions from the victims' close relatives. Of course, a case in point remains Lord Justice Gibson's comments when, acquitting several police officers of murder of alleged republican paramilitaries, he praised them for bringing the dead men to justice and "in their case the final courts of justice". ${ }^{43}$ Given the anti-terrorist legislation and policy and the sensitive cases they were called upon to handle, it was hard for the judiciary, no matter how rigorously independent, to preserve an image of equal justice. The cases of security forces personnel enjoying some implicit level of immunity while dealing with terrorist 
suspects, has somewhat diluted and tainted the judiciary's idea of the law that should equally be applicable to all. Such cases have undermined the authority of the courts and the relevance of the law for all. Moreover, they have convinced nationalists that the law and the courts were unable to check the use of force by unionist security forces against them. The Good Friday Agreement opened a new era for lawyers, the judiciary and the courts. In a transition period, reforming the criminal justice system had become a necessity, a task that was entrusted to a Review, 'a mechanism with an independent element' that was to make recommendations for a possible reform. This meant that the government still played a major role in it and that the Review would not have the independence enjoyed by the Patten Commission on the police reform. This became obvious in the final report which some expected could have been more ambitious. After decades of subservience to emergency provisions, the criminal justice system required a radical change, root and branch. The Justice (Northern Ireland) Act 2002 made provision for many of the Review recommendations: the appointment of an independent judicial appointments' commission, ${ }^{44}$ the new Prosecution Service for Northern Ireland, ${ }^{45}$ the creation of the new offices of Attorney General for Northern Ireland, ${ }^{46}$ Advocate General, ${ }^{47}$ Chief Inspector for Criminal justice ${ }^{48}$ and Lay Magistrate, ${ }^{49}$ reform of the youth justice system $^{50}$ and new regulations on the use of courtroom symbols, flags and oath of allegiance. ${ }^{51}$ All these changes aimed at a greater accountability and transparency. Moreover, the introduction of a Human Rights principles now entrenched in UK legislation is likely to develop a human rights culture among lawyers and the judiciary and change their approach to erstwhile criminal problems. The same may be said for all those concerned with the criminal justice system including the new PSNI personnel. Lawyers may not for long keep avoiding considering the genuine nature of the conflicts they will have to deal with and they may have to take into account and uphold values that may have a wider scope across the social and ideological spectrum. Yet, owing to the current institutional deadlock, few reforms have so far been implemented.

Outside the formal process, it is interesting to mention a specific transitional justice experiment that has been set up independently to deal with youth justice. It is organised along specific rules to curb criminal activity: restorative justice schemes which are nonviolent alternatives to punishment beatings are being operated within some of the republican and loyalist working class areas. ${ }^{52}$ The local organisations are Community Restorative Justice Ireland which started projects in 1999 and now operates in several parts of the province. Its counterpart is Greater Shankill Alternatives that deals with offenders from 10 to 18 . These develop a contract that includes making amends to the victim, community reparation and strategies for self-improvement. The PSNI has also launched its own restorative justice projects that address retail theft and a variety of minor offences. Finally, the Justice (Northern Ireland) Act 2002 establishes conferencing for juveniles, similar to that which is in operation in New Zealand and which was highly recommended by the Review. ${ }^{53}$ The administration of the youth conferences is a new branch of the criminal justice system called the Youth Justice Agency which was started in March 2003, outside the full implementation of the Act. Thus there are two differing perspectives on restorative justice in Northern Ireland, either stemming from community-based schemes or statutorybased schemes, emphasising the community divide with distinctive needs and mutual distrust. Although that area of justice cannot for the time being find common ground among all the parties concerned, whether they be state or non-state agents, there is no denying that progress is being made towards establishing peace in the community.

Law has been a central issue in Northern Ireland's conflict and is likely to play a major role in the development of the province. It has to bear relation to the legal system in order to gain the confidence and respect of all. It will have to face major challenges as to accountability and justice in a democratic society reconciling a sharply divided community. All in all the field of criminal justice has undergone conducive changes while the local institutions have not yet been restored to allow a full implementation of the Justice Act 2002.

The debate about how to acknowledge and deal with the past is currently taking place in Northern Ireland though the political process remains unstable and volatile, which undercuts the potential for creating a wider reparation 
policy. Even though the Good Friday Agreement finds itself in a deadlock and if a number of provisions still remain to be implemented, this paper has shown that major transformations have already taken place in a phase of transition. It shows that despite the institutional start-and-stop strategy, ordinary citizens are pressing for and committed to changes which many of them have been instrumental in achieving. Even though Northern Ireland is a case apart, transitional justice in Northern Ireland is more than mere theoretical debate among academic experts. Realistic projects have taken shape on the ground thanks to the involvement of local organisations whose strategy is geared to change and peacemaking. However, the state authorities have dragged their feet before taking complementary measures outside the Agreement such as commissioning inquiries into major murder cases. On the whole they seem to be reluctant, as well as local political parties, to set up a Truth Commission to address the past which some would prefer to let it sink into oblivion. Though there is still frustration and anger at the grassroots level to establish truth and accountability, the peace building process is under way. Political engagement with the debate about dealing with the past, and a more open discussion about truth and justice issues from all sides and including the state, still needs to mature. Present political developments in Northern Ireland may eventually make for such peace building

\footnotetext{
${ }^{1}$ A.James McAdams (ed), Transitional Justice and the Rule of Law in New Democracies, Notre Dame, IN : University of Notre Dame Press, 1997.
}

2 Ultra vires [Latin: beyond powers] Describing an act by a public authority, company or other body that goes beyond the limits of the powers conferred on it. 'Ultra vires' acts are invalid. The 'ultra vires' doctrine applies to all powers, whether created by statute or by a private document or agreement. from A Dictionary of Law, OUP, 1994, p.410.

${ }^{3}$ Ruti Teitel, Transitional Justice, Oxford : OUP, 2002.

${ }^{4}$ M.O'Rawe and L.Moore, Human Rights on Duty: Principles for Better Policing: International Lessons for Northern Ireland, Belfast : Committee on the Administration of Justice, December 1997.

5 Ameur Zemalli, "Reparations for Victims of violations of International Humanitarian Law", seminar on the Right to restitution, Compensation and Rehabilitation for Victims of Gross Violations of Human Rights and Fundamental Freedoms, Maastricht : Netherlandds Institute of Human Rights, 1992, 61-75.

${ }^{6}$ United Nations, Economic and Social Council, The Right to Restitution, Compensation and Rehabilitation for Victims of Gross Violations of Human Rights and Fundamental freedms: Final Report by Theodor Van Boven, 2 July 1993.

${ }^{7}$ Protocol Additional to the Geneva Conventions of 12 August 1949 and Relating to the Protection of Victims of InternationalArmed Conflicts (Protocol I) (1977), and Protocol Additional to the Geneva Conventions of 12 August 1949, and Relating to the Protection of Victimsof Non-International Artmed Conflicts (Ptotocol II) (1977). The two Protocols were actually signed in December 1977 but the Geneva Conventions Amendment Act 1995 providing for ratification was enacted after the Northern Ireland ceasefires.

${ }^{8}$ South African Constitution, Epilogue.

9 Azanian Peoples'Organisation (AZAPO) and Others v. President of the Republic of South Africa and Others, (1996), (4) SA LR 671 (CC).

${ }^{10}$ House of Commons Official Report, 29 January 1998.

${ }^{11}$ Weston Park Statement, 1 August 2001.

${ }^{12}$ For example, the four joined cases of Jordan, Kelly, McKerr and Shanaghan v. United Kingdom, Application No. 24746/94; 30054/96; 28883/95; and 37715/97, respectively, judgement May 4, 2001. See, Fionnuala Ní Aoláin, Accountability and the Right to Life in Northern Ireland Issue 5 E.H.R.L.R. (2002).

${ }^{13}$ See www.nihc.org

${ }^{14}$ The Report of the Healing Through Remembering Project (HTR: Belfast, 2002), see http://www.healingthroughremembering.org

${ }^{15}$ The Report had been commissionned by Secretary of State for Northern Ireland Mo Mowlam in October 1997 and was released on 29 April 1998.

${ }^{16}$ Bloomfield Report, We Will Remember Them, April 1978. 
${ }^{17}$ Hugh Jordan v. the United Kingdom (no. 24746/94), McKerr v. the United Kingdom (no. 28883/95), Kelly and others v. the United Kingdom (no. 30054/96), Shanaghan v. the United Kingdom (no. 37715/97), Judgement May 4, 2001; McShane v. the United Kingdom (no. 43290/98), Judgement May 28, 2002.

${ }^{18} \mathrm{See} \mathrm{http://www.policeombudsman.org//Publicationsuploads}$

19 "Police Chief Calls for Truth and reconciliation in Ulster", The Guardian, 23 February 2004.

${ }^{20}$ NI Commission « could heal the wounds », BBC News 18 February 2004.

${ }^{21}$ The Irish Times, 19 February 2004.

${ }^{22}$ Recent figures put the final cost at over $\$ 155 \mathrm{~m}$ : see «Bloody Sunday Inquiry has cost $£ 154 \mathrm{~m}$ », Belfast Telegraph, 27 January 2005

${ }^{23}$ The Irish Times, 15 April 2004.

${ }^{24}$ Paul Murphy, The Irish Times, 2 June 2004.

25 "Lost lives : the stories of the men, women and children who died as a result of the Northern Ireland Troubles", David McKittrick, Seamus Kelters, Brian Feeney and Chris Thornton. Edinburgh: Mainstream publishing company, 1999. ISBN 1-84018-227-X

${ }^{26}$ Irish News, 31 May 2004.

27 "No banana republic ways here, Mr Orde", Newsletter, 31 May 2004.

${ }^{28}$ Northern Ireland (Sentences) Act 1998.

${ }^{29}$ Amnesty International, 1978, Report of an Amnesty International mission in Northern Ireland (it reaffirmed and presents new evidence of use of systematic torture by authorities in Northern Ireland). Bennett Report (1979) Report of the Committee of Inquiry into Police Interrogation Procedures in Northern Ireland. Cmnd. No. 7497. London: HMSO. The European Commission on Human Rights, 1978, found the British government guilty of torture of republican prisoners. The European Court of Human Rights, January 1978, however decided that the Commission was wrong to use the word 'torture' but did agree that the internees had been subjected to 'inhuman and degrading treatment'.

${ }^{30}$ The Independent Commission on Policing for Northern Ireland was set up on 3 June 1998.

${ }^{31}$ Police (Northern Ireland) Act 1998 and Police (Northern Ireland) Act 2000.

${ }^{32}$ Patten Report, September 1999, p.7.

33 "The Brixton Disorders - Report of an inquiry », the Rt Hon. The Lord Scarman, HMSO, London, 1981.

${ }^{34}$ Nevin Farrell, Belfast Telegraph, 07 February 2005

${ }^{35}$ Belfast Telegraph, 28 November 2000.

${ }^{36}$ Livingstone, Steven, in Human Rights, Equality and Democratic Renewal in Northern Ireland, Harvey Colin, (Edit.), Oxford: Hart Publishing, 2001, 150

${ }^{37} \mathrm{http}: / /$ cain.ulst.ac.uk/sutton/index.html

${ }^{38}$ Stalker John, Stalker, Middlesex : Penguin, 1988.

${ }^{39}$ Livingstone, Ibid., 137.

${ }^{40}$ Lawyers Committee on Human Rights, Human Rights and Legal defense in Northern Ireland, 1993, 41.

${ }^{41}$ Livingstone, Ibid., p.132.

${ }^{42}$ Morison.J. and Leith.P., The Barrister's World, Milton Keynes: Open University Press, 1992, p.40.

${ }^{43}$ R. v. Montgomery, 1984. Lord Gibson and his wife were killed in a bomb attack by the IRA on 27 April 1987.

${ }^{44}$ Justice (Northern Ireland) Act 2002, s.3

${ }^{45}$ Ibid, s.29 (1)

${ }^{46}$ Ibid, s.22 (1)

${ }^{47}$ Ibid, s.27

${ }^{48}$ Ibid, s. 45

${ }^{49}$ Ibid, s.9

${ }^{50} \mathrm{Ibid}$, Part IV, ss.53-65.

${ }^{51}$ Ibid, Part V, ss.66-67.

${ }^{52}$ McEvoy.K. and Mika.H., "Restorative Justice in Conflict: paramilitarism, community and the construction of legitimacy in Northern Ireland", Contemporary Justice Review, 2001, 4, (3-4), p.291-319.

${ }^{53}$ Criminal Justice Review Group, 2000, p.205. 


\section{REFERENCES}

Boyle, K., Hadden T., Hillyard P. 1975. Law and State, London: Martin Robinson.

Campbell, Colm, Fionuala Ni Aolain and Colin Harvey. 2003. "The Frontiers of Legal Analysis: Reframing the Transition in Northern Ireland", Modern Law Review, Vol.66, May, 334.

McKittrick, David, Seamus Kelters, Brian Feeney and Chris Thornton. 1999. "Lost lives: the stories of the men, women and children who died as a result of the Northern Ireland Troubles", Edinburgh: Mainstream publishing company.

Teitel. R. 2002. Transitional Justice, Oxford: OUP. 